\title{
Zika virus outbreak in 19 English- and Dutch-speaking Caribbean countries and territories, 2015-2016
}

\author{
Lorraine Francis, ${ }^{1}$ Shelly-Ann Hunte, ${ }^{2}$ Ann Marie Valadere, ${ }^{3}$ Karen Polson-Edwards, ${ }^{1}$ \\ Virginia Asin-Oostburg, ${ }^{1}$ and C. James Hospedales ${ }^{1}$
}

Suggested citation Francis L, Hunte SA, Valadere AM, Polson-Edwards K, Asin-Oostburg V, Hospedales CJ. Zika virus outbreak in 19 English- and Dutch-speaking Caribbean countries and territories, 2015-2016. Rev Panam Salud Publica. 2018;42:e120. https:// doi.org/10.26633/RPSP.2018.120

ABSTRACT Surveillance for Zika virus was enhanced in the English-and Dutch-speaking Caribbean following emergence of the virus in Brazil in May 2015. The first autochthonous case of Zika in the Caribbean was reported by Suriname in November 2015, and the virus subsequently spread rapidly throughout the region. Caribbean Public Health Agency (CARPHA) member states (CMS) reported clinically suspected cases of Zika and submitted serum specimens to the agency for laboratory investigation. A patient was considered a confirmed case if Zika virus was detected by real-time reverse transcription-polymerase chain reaction (RT-PCR) assay or serological test. Due to the documented link between 1) Zika virus and congenital syndrome, and 2) Zika virus and Guillain-Barré syndrome (GBS), data on both of these disease outcomes were extracted from country and regional reports. This special report describes the epidemiology of laboratory-confirmed Zika cases reported to CARPHA, including links with both congenital syndrome and GBS, for 19 English- and Dutch-speaking Caribbean countries during the epidemic period (1 October 2015-29 December 2016).

Keywords Communicable diseases, emerging; epidemics; Zika virus; Caribbean region.

During 1 October 2015 to 29 December 2016, 5614 cases from 19

\footnotetext{
Division of Surveillance, Disease Prevention and Control, Communicable Diseases and Emergency Response Department, Caribbean Public Health Agency, Port-of-Spain, Trinidad. Send correspondence to: Lorraine Francis, francilo@carpha.org

2 Division of Policy, Planning and Research, Caribbean Public Health Agency, Port-of-Spain, Trinidad.

Division of Surveillance, Disease Prevention and Control, Laboratory Services and Networks Department, Caribbean Public Health Agency, Port-of-Spain, Trinidad
}

Caribbean Public Health Agency (CARPHA) member states (CMS) were tested for arboviral pathogens. Of these, 1447 cases tested positive for Zika virus. The majority of cases were female $(83.0 \%)$, of which $614(51.0 \%)$ were pregnant. A total of $59 \%$ of cases were $20-39$ years old (median, 30 years; range, 5 days-90 years). Rash, fever, and arthralgia affected $87.0 \%, 63.0 \%$, and $60.0 \%$ of all reported cases respectively. Four confirmed cases of congenital syndrome and 121 cases of Guillain-Barré syndrome
(GBS), a severe neurological condition in adults, were reported from three and 10 countries respectively.

The emergence of Zika virus in the Caribbean underscores the ongoing challenge posed by arboviral infections and the need for continued vigilance and investment in surveillance systems and innovative prevention and control strategies.

During 2016, the Director General of the World Health Organization (WHO) declared a Public Health Emergency of 
International Concern (PHEIC) as a result of the complications associated with the Zika virus outbreak in Latin America and the Caribbean (1). The Caribbean has a long history with arboviral diseases, including yellow fever (2), dengue (3), chikungunya (4), and, more recently, Zika $(5,6)$. Zika virus (family Flaviridae) is transmitted primarily through the bite of infected Aedes mosquitoes, including Aedes aegypti (7). Ae. aegypti is broadly distributed throughout the Caribbean (8), and climate, particularly temperature and rainfall, are key drivers of the vector's ecology.

In urban environments, Zika shares a similar epidemiology, clinical presentation, and transmission cycle with chikungunya and dengue but has generally been associated with milder illness (9). Typical clinical symptoms of the disease include fever, rash, arthralgia, and conjunctivitis (10). In recent years, Zika virus infection during pregnancy has been shown to be associated with congenital anomalies including microcephaly in babies born to infected mothers (11). Infection with the virus has also been associated with GBS (12).

First isolated from a rhesus monkey in the Zika Forest in Uganda in 1947 (7), serological evidence for the virus in humans during epidemics on Yap Island, Micronesia, in 2007 and French Polynesia in 2013 are well-documented $(9,13)$. The first autochthonous case of Zika in the Caribbean was reported by Suriname in November 2015 following detection of the virus at the CARPHA laboratory in Trinidad. By December 2016, 1055851 autochthonous suspected cases and 3212 confirmed cases were reported by the English- and Dutch-speaking Caribbean CMS (14).

CARPHA is the regional institution charged with providing public health services to the CMS (15). One key function of the agency is to support CMS in preparing for and responding to public health emergencies and threats (15). This is usually performed in close collaboration with regional and international partners. This report describes the epidemiology of laboratory-confirmed Zika cases reported to CARPHA, including links with both congenital syndrome and GBS, for 19 English- and Dutchspeaking Caribbean countries during the epidemic period (1 October 2015-29 December 2016).

\section{MATERIALS AND METHODS}

\section{Setting}

The Caribbean comprises countries to the southeast of the Gulf of Mexico and north of the American mainland, east of Central America, and north of South America (16). Many of the countries have a tropical to subtropical climate with occasional tropical storms and hurricanes. While all CMS are classified as Small Island Developing States, there is a wide range in sizefrom Guyana, at $219470 \mathrm{~km}^{2}$, to St. Kitts and Nevis, at $360 \mathrm{~km}^{2}$ - and population-from Montserrat, with just over 5000 people, to Haiti, with more than 10000000 (17).

CARPHA, established in July 2011, provides CMS with technical support in public health, including regional surveillance, laboratory services, training, and applied research (18). Health services in CMS are delivered by varying combinations of national public-private mix. In some CMS, primary and secondary care services are provided by health centers or polyclinics, and some hospitals. A small number of CMS can provide tertiary services in-country, while in others, preestablished mechanisms exist with neighboring countries for tertiary service provision. Seven CMS have a National Public Health Laboratory for the provision of specialist laboratory support, while in the remaining 19 this function is provided by a designated hospital laboratory. Diagnostic capacity within CMS differs, and the CARPHA laboratory in Trinidad acts as the regional reference and referral laboratory (19). CMS routinely refer specimens for testing to CARPHA to support surveillance.

\section{Case definition}

Surveillance for Zika in CMS began on 3 November 2015 following detection of the first autochthonous case of vector-borne transmission of the virus. Syndromic surveillance is well established in the Caribbean, with CMS routinely reporting cases of undifferentiated fever (UDF) to the CARPHA surveillance unit.

Case definitions as outlined in the Pan American Health Organization (PAHO) Zika virus infection Epidemiological Update were modified for the characterization of cases at the beginning of the epidemic (20). The modified criteria included fever $\geq 37.2{ }^{\circ} \mathrm{C}$ and history of travel to a country endemic for Zika or experiencing a Zika virus outbreak (21). As the epidemic continued and more information regarding clinical presentation of the virus became available, case definitions were reviewed and updated. From April 2016 onward, cases were characterized according to the updated PAHO case definitions (22). A suspected case was defined as a patient with a rash (usually pruritic and maculopapular) with two or more of the following signs or symptoms: fever $\left(\geq 38.5^{\circ} \mathrm{C}\right)$, conjunctivitis (non-purulent or hyperemic), arthralgia, myalgia, and peri-articular edema, who, in the two weeks prior to onset, traveled to or resided in a geographic area with known local transmission of the Zika virus (or known vector presence) or had unprotected sex in the two weeks prior to onset with a person who traveled in the previous eight weeks to a geographic area with known local transmission of the Zika virus (or known vector presence) (22). Confirmed cases were defined as patients who met the criteria for a suspected case with laboratory confirmation of recent Zika virus infection-i.e., 1) ribonucleic acid (RNA) or Zika virus antigen in any specimen (serum, urine, saliva, tissue, or whole blood), or positive Zika immunoglobulin $\mathrm{M}$ ( $\operatorname{IgM}$ ) antibodies and a plaque-reduction neutralization test -90\% (PRNT-90) (the serum titer required to reduce viral plaques by $90 \%$ ) for Zika virus titers equal to 20 and four or more times greater than the titers for other flaviviruses, and exclusion of other flaviviruses, or 2) in autopsy specimens, detection of the viral genome (in fresh or paraffin tissue) by molecular techniques, or detection by immunohistochemistry (22).

Due to the documented causal link between Zika and congenital syndrome, the PAHO case definition was used for the identification of congenital cases associated with the virus (20). A suspected case was a live newborn who presented with microcephaly or other congenital malformation of the central nervous system whose mother had 1) traveled to or resided in an area where Zika virus vectors were present during her pregnancy, or 2) had unprotected sex during pregnancy with a partner who resided in or traveled to an area with the presence of Zika virus vectors (22). 
A confirmed case of congenital syndrome associated with Zika virus was defined as a live newborn who met the criteria for a suspected case of congenital syndrome associated with Zika virus, and had a specimen with laboratory detection of Zika virus, with or without detection of other pathogens (22). The data on Zika virus and congenital syndrome were extracted from country and regional reports and are presented below, along with data on GBS, a disease outcome that has also been linked with the virus.

\section{Sample collection and laboratory analysis}

Serum samples from CMS were shipped to the CARPHA-Trinidad laboratory for testing. CMS routinely sent specimens for testing during the outbreak, with the exception of Jamaica and Suriname. These two CMS sent samples to confirm their first cases, as well as a few others; after that, in-country testing was developed with support from CARPHA and PAHO. Samples from Sint Maarten were sent to the Analytisch Diagnostisch Centrum N.V. in Curaçao for testing.

Serum samples from patients in the acute phase of illness were tested using a fluorescent, probe-based, Trioplex realtime reverse transcription-polymerase chain reaction (RT-PCR) assay (TaqMan $\AA$, Applied Biosystems, Waltham, MA, USA) developed by the U.S. Centers for Disease Control and Prevention (CDC) for use in detecting chikungunya, dengue, and Zika, in accordance with the PAHO algorithm for detection of Zika virus (23). An RT-PCR assay was used for detection of Zika virus in samples collected within 1-5 days of onset of illness. Samples taken $\geq 6$ days after onset of illness were tested for Zika virus by either RT-PCR or PRNT-90, and by IgM ELISA (Focus Diagnostics Inc., Cypress, CA, USA) for dengue and chikungunya virus. Immunoglobulin G (IgG) testing was not performed. Date of specimen collection was used as a proxy in instances where the date of onset of illness was not provided. Laboratory confirmation for all cases was performed until autochthonous transmission was established within individual CMS. Subsequently, laboratory confirmation was performed on samples from highrisk patients (people $<5$ years old and $\geq$
65 years old, hospitalized patients, pregnant women, patients with comorbidities, fatal cases, and suspected cases from new geographic areas).

\section{Data capture and analysis}

In December 2015, a Zika database was developed using Microsoft Excel (Microsoft, Redmond, WA, USA) to capture information on specimens submitted to the CARPHA-Trinidad laboratory for Zika testing. Data were uploaded weekly from the CARPHATrinidad Laboratory Information System to the Zika database. The General Health Care Section of the Department of Collective Prevention Services at the Ministry of Public Health, Social Development and Labour (Ministerie van Volksgezondheid, Sociale Ontwikkeling en Arbeid Zaken, VSA) in Philipsburg, Sint Maarten, submitted a line listing of Zika cases to the CARPHA surveillance unit for inclusion in the Zika database. Data validation was done in collaboration with CMS as necessary. Statistical analyses were performed using Microsoft Excel and Stata version 12 software (StataCorp, College Station, TX, USA). Fisher's exact test was used to compare differences in proportions of reported clinical symptoms by age groups and sex; $P$ values $<0.05$ were considered statistically significant. Identifying variables were excluded from the dataset that was used for analysis.

\section{RESULTS}

\section{Trends over time}

During the epidemic period, 1 October 2015 to 29 December 2016, a total of 5614 cases from 19 CMS were tested for arboviral pathogens. Of these, 1447 cases tested positive for Zika virus. While Zika virus was the arboviral pathogen targeted for detection, chikungunya and dengue were also confirmed, at much lower levels (Figure 1). Cases of chikungunya and dengue represented $<1 \%$ of all cases tested. There were no patients with evidence of coinfection with dengue or chikungunya.

The first four laboratory-confirmed cases of Zika were reported by Suriname, with reported onset of illness in October 2015. No significant increase in the UDF syndrome was reported by Suriname during September 2015; however, an increase in reported cases was observed from epidemiological week (EW) 44 (beginning 1 November 2015).

The virus spread rapidly to other CMS, and subsequent cases from the Englishand Dutch-speaking Caribbean were confirmed, with reported onset of illness in January 2016. There was a sustained increase in reported cases, which peaked in August 2016. A sharp reduction in cases occurred in September-December 2016.

\section{Laboratory results}

During the review period, there was an overall Zika test positivity of $25.8 \%$.

\section{FIGURE 1. Laboratory-confirmed cases of Zika, chikungunya, and dengue in 19 Caribbean Public Health Agency (CARPHA) member states, 1 October 2015-29 December 2016}

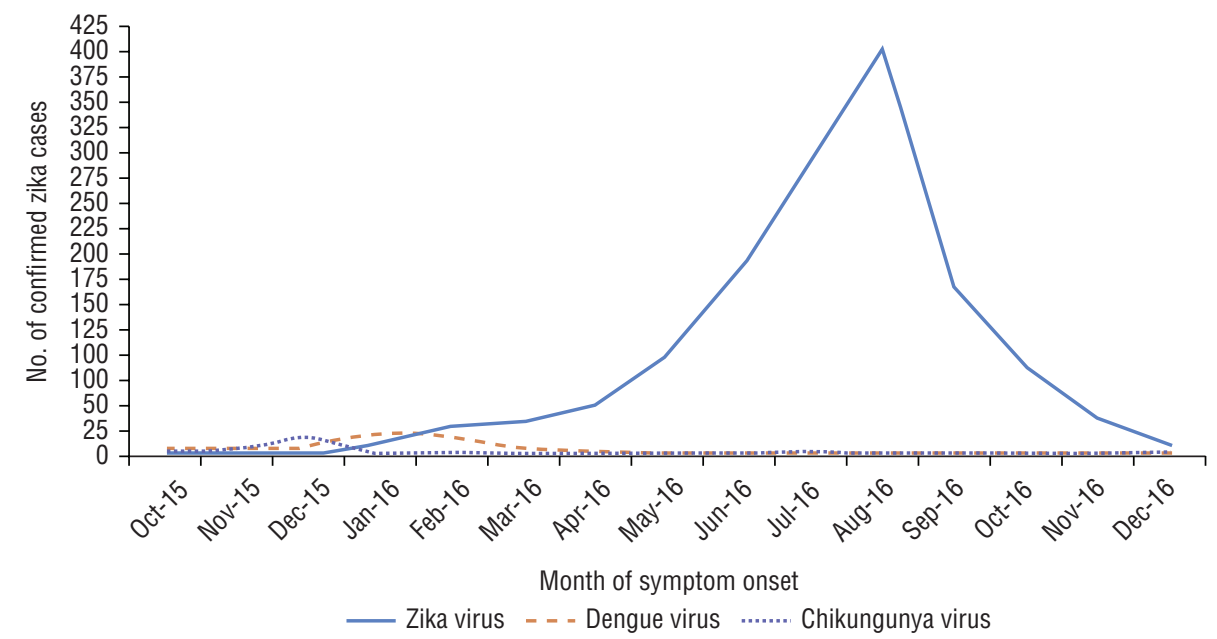

Source: CARPHA laboratory and surveillance data 2015-2016. 
A total of 1301 of the 1447 specimens that tested positive for Zika virus were confirmed by RT-PCR only. There was some variation across countries in sample selection for testing, and the proportion of patients who tested positive for Zika ranged from $4.0 \%-38.1 \%$. Approximately $50.0 \%$ of positive cases were from Trinidad and Tobago (Table 1).

\section{Case characteristics}

Of the 1447 confirmed cases, 1200 $(83.0 \%)$ were female, of which 614 $(51.0 \%)$ were pregnant. The age of cases ranged from 5 days to 90 years (median, 30 years); 59\% were 20-39 years old (Table 2).

\section{Clinical characteristics}

The symptoms most commonly reported by all cases were rash $(87.0 \%)$, fever $(63.0 \%)$, and arthralgia $(60.0 \%)$. Conjunctivitis was reported by $33.0 \%$ of cases. Other symptoms included headache, chills, and myalgia.

There was a statistically significant difference in the proportion of males who reported rash, fever, conjunctivitis, headache, chills, and myalgia when compared to females. There was also a statistically significant difference in the proportion of adults who reported fever, arthralgia, and myalgia when compared to children (Table 3).

\section{Hospitalizations and deaths}

No Zika-related hospitalizations were reported; however, Suriname reported four deaths associated with the virus during the review period (14). It is unknown whether these cases had preexisting comorbidities prior to infection with the virus.

\section{Reported disease outcomes}

Four confirmed cases of congenital syndrome associated with Zika virus infection were reported from three countries during the period: two in Suriname and one each in Grenada and Trinidad and Tobago. A total of 121 cases of GBS were reported from 10 countries, with 13 reported cases laboratory-confirmed for Zika virus (Table 4).

TABLE 1. Laboratory-confirmed Zika cases in 19 Caribbean Public Health Agency (CARPHA) member states, 1 October 2015-29 December 2016

\begin{tabular}{|c|c|c|c|}
\hline Country & $\begin{array}{l}\text { Total cases for which } \\
\text { samples were tested }\end{array}$ & Zika-positive cases & Test positivity (\%) \\
\hline Anguilla & 60 & 20 & 33.3 \\
\hline Antigua \& Barbuda & 123 & 24 & 19.5 \\
\hline Bahamas & 99 & 9 & 9.1 \\
\hline Barbados & 130 & 40 & 30.8 \\
\hline Belize & 392 & 61 & 15.6 \\
\hline British Virgin Islands & 180 & 17 & 9.4 \\
\hline Cayman Islands & 213 & 28 & 13.2 \\
\hline Dominica & 381 & 78 & 20.5 \\
\hline Grenada & 179 & 43 & 24.0 \\
\hline Guyana & 198 & 42 & 21.2 \\
\hline Jamaica $^{\mathrm{a}}$ & 223 & 9 & 4.0 \\
\hline Montserrat & 31 & 5 & 16.1 \\
\hline Saint Lucia & 192 & 52 & 27.1 \\
\hline Sint Maarten ${ }^{b}$ & 383 & 146 & 38.1 \\
\hline St. Kitts \& Nevis & 210 & 39 & 18.6 \\
\hline $\begin{array}{l}\text { St. Vincent \& the } \\
\text { Grenadines }\end{array}$ & 302 & 83 & 27.5 \\
\hline Suriname ${ }^{a}$ & 33 & 6 & 18.0 \\
\hline Trinidad \& Tobago & 2150 & 721 & 33.5 \\
\hline Turks \& Caicos Islands & 154 & 24 & 15.6 \\
\hline Total & 5614 & 1447 & 25.8 \\
\hline
\end{tabular}

\begin{tabular}{|c|c|}
\hline Characteristics & Confirmed cases $(n=1447)$ \\
\hline \multicolumn{2}{|l|}{$\overline{\operatorname{Sex}(\%)}$} \\
\hline Male & $237(16.0)$ \\
\hline Female & $1200(83.0)$ \\
\hline \multicolumn{2}{|l|}{ Pregnant (\%) } \\
\hline Yes & $614(51.0)$ \\
\hline Unknown & $10(1.0)$ \\
\hline \multicolumn{2}{|c|}{ Median age, years (IQR $\left.{ }^{\mathrm{a}}\right)$} \\
\hline All patients & $30(15)$ \\
\hline Pregnant women & $28(9)$ \\
\hline Children $^{b}$ & $7.5(8)$ \\
\hline \multicolumn{2}{|l|}{ Age group, years (\%) } \\
\hline $0-4$ & $55(4.0)$ \\
\hline $5-9$ & $48(3.0)$ \\
\hline $10-14$ & $44(3.0)$ \\
\hline $15-19$ & $66(5.0)$ \\
\hline $20-24$ & $188(13.0)$ \\
\hline $25-29$ & $264(18.0)$ \\
\hline $30-34$ & $248(17.0)$ \\
\hline $35-39$ & $156(11.0)$ \\
\hline $40-44$ & $93(6.0)$ \\
\hline $45-49$ & $54(4.0)$ \\
\hline $50-54$ & $59(4.0)$ \\
\hline $55-59$ & $33(2.0)$ \\
\hline $60-64$ & $24(2.0)$ \\
\hline$\geq 65$ & $115(8.0)$ \\
\hline $\begin{array}{l}\text { Source: CARPHA lab } \\
\text { 2015-2016. } \\
\text { a IQR: interquartile ran } \\
\text { b } 16 \text { years or younger. }\end{array}$ & ry and surveillance data \\
\hline
\end{tabular}


TABLE 3. Clinical manifestation of Zika in laboratory-confirmed cases in 19 Caribbean Public Health Agency (CARPHA) member states, 1 October 2015-29 December 2016

\begin{tabular}{|c|c|c|c|c|c|c|c|c|c|c|c|c|}
\hline \multirow[t]{2}{*}{ Clinical manifestation } & \multicolumn{2}{|c|}{$\begin{array}{c}\text { All cases } \\
(n=1447)\end{array}$} & \multicolumn{2}{|c|}{$\begin{array}{c}\text { Adults } \\
(n=1289)\end{array}$} & \multicolumn{2}{|c|}{$\begin{array}{l}\text { Children }^{a} \\
(n=158)\end{array}$} & \multicolumn{2}{|c|}{$\begin{array}{c}\text { Male } \\
(n=237)\end{array}$} & \multicolumn{2}{|c|}{$\begin{array}{c}\text { Female } \\
(n=1200)\end{array}$} & \multicolumn{2}{|c|}{$\begin{array}{l}\text { Pregnant women } \\
\qquad(n=614)\end{array}$} \\
\hline & No. & $\%$ & No. & $\%$ & No. & $\%$ & No. & $\%$ & No. & $\%$ & No. & $\%$ \\
\hline Rash & 1255 & 87.0 & 1111 & 86.0 & 144 & 91 & 191 & 81.0 & 1055 & $89.0^{\mathrm{b}}$ & 560 & 91.0 \\
\hline Fever & 913 & 63.0 & 791 & 61.0 & 122 & $77^{b}$ & 202 & 86.0 & 707 & $59.0^{\mathrm{b}}$ & 330 & 54.0 \\
\hline Arthralgia & 874 & 60.0 & 809 & 63.0 & 65 & $41^{b}$ & 152 & 64.0 & 717 & 60.0 & 341 & 56.0 \\
\hline Conjunctivitis & 476 & 33.0 & 431 & 33.0 & 45 & 28 & 94 & 40.0 & 377 & $31.0^{\mathrm{b}}$ & 169 & 28.0 \\
\hline Headache & 200 & 14.0 & 176 & 14.0 & 24 & 15 & 53 & 22.0 & 147 & $12.0^{\mathrm{b}}$ & 46 & 7.0 \\
\hline Chills & 171 & 12.0 & 158 & 12.0 & 13 & 8 & 43 & 18.0 & 128 & $11.0^{\mathrm{b}}$ & 52 & 8.0 \\
\hline Myalgia & 147 & 10.0 & 138 & 11.0 & 9 & $6^{b}$ & 38 & 16.0 & 108 & $9.0^{\mathrm{b}}$ & 26 & 4.0 \\
\hline
\end{tabular}

Source: CARPHA laboratory and surveillance data 2015-2016.

a 16 years or younger.

${ }^{\mathrm{b}} P<0.05$ for Fisher's exact test.

TABLE 4. Congenital syndrome and Guillain-Barré syndrome (GBS) associated with Zika virus infection in 19 Caribbean Public Health Agency (CARPHA) member states, 1 October 2015-29 December 2016

\begin{tabular}{|c|c|c|c|c|}
\hline Country & $\begin{array}{c}\text { Number of pregnant women } \\
\text { tested for Zika virus }\end{array}$ & $\begin{array}{c}\text { Confirmed congenital syndrome } \\
\text { associated with Zika virus } \\
\text { infection }^{\mathrm{a}}\end{array}$ & Reported cases of GBS & $\begin{array}{c}\text { Cases of GBS laboratory- } \\
\text { confirmed for Zika }\end{array}$ \\
\hline Anguilla & 1 & 0 & 0 & 0 \\
\hline Antigua \& Barbuda & 13 & 0 & 0 & 0 \\
\hline Bahamas & 2 & 0 & 0 & 0 \\
\hline Barbados & 32 & 0 & 4 & 0 \\
\hline Belize & 13 & 0 & 0 & 0 \\
\hline British Virgin Islands & 2 & 0 & 0 & 0 \\
\hline Cayman Islands & 1 & 0 & 0 & 0 \\
\hline Dominica & 9 & 0 & 2 & 0 \\
\hline Grenada & 7 & 1 & 10 & 3 \\
\hline Guyana & 4 & 0 & 13 & 0 \\
\hline Jamaica & 0 & 0 & 30 & 4 \\
\hline Montserrat & 0 & 0 & 0 & 0 \\
\hline Saint Lucia & 37 & 0 & 6 & 0 \\
\hline Sint Maarten & 6 & 0 & 0 & 0 \\
\hline St. Kitts \& Nevis & 7 & 0 & 1 & 0 \\
\hline St. Vincent \& the Grenadines & 20 & 0 & 7 & 0 \\
\hline Suriname & 0 & 2 & 15 & 4 \\
\hline Trinidad \& Tobago & 459 & 1 & 33 & 2 \\
\hline Turks \& Caicos Islands & 1 & 0 & 0 & 0 \\
\hline Total & 614 & 4 & 121 & 13 \\
\hline
\end{tabular}

Source: CARPHA laboratory and surveillance data 2015-2016.

a (14).

and to self-quarantine to minimize spread to other family members and the community. Island-wide public awareness campaigns targeting both residents and visitors were carried out, with a focus on densely populated areas; activities included posting flyers and banners and disseminating public service announcements. Vector control measures were stepped up in all CMS in communities, schools, health facilities, and hotels. Surveillance for acute flaccid paralysis
(AFP), a regional syndrome routinely used for the early detection of poliovirus, was used to detect cases of GBS associated with the Zika virus.

In the post-epidemic period, several workshops and meetings, including lessons on identifying the virus, were held in collaboration with partner agencies. Some CMS developed 1) support packages (counseling and social protection) for families caring for children with microcephaly and other congenital anomalies, and 2) structured assessment protocols for monitoring child growth and development.

\section{DISCUSSION}

During the epidemic period, 1 October 2015-29 December 2016, 5614 cases from 19 CMS were tested for arboviral pathogens. Approximately $40 \%$ of specimens received at CARPHA-Trinidad were from Trinidad and Tobago. This can be 
explained by the close proximity of Trinidad's Public Health Laboratory to CARPHA-Trinidad. Of the 5614 cases, 1447 tested positive for Zika virus. The majority of confirmed cases were female $(83 \%)$, and approximately $50 \%$ of the women were pregnant. This was expected, as pregnant women were one of the high-risk groups preferentially sampled, due to the association of congenital syndrome with Zika virus infection. Although no CMS reported sexually transmitted Zika cases, transmission of the virus via sex is plausible. Zika cases occurred in all age groups, but the age group most frequently tested was 20-39 years, similar to the outbreaks in Yap Island, Micronesia, and Salvador, Brazil $(9,25)$. This age group included women of child-bearing age, suggesting both shortand long-term economic effects from the disease, and a possible increased burden on health and social systems, due to complications arising from Zika infection during pregnancy. Of the 614 pregnant women tested for Zika virus, four cases of confirmed congenital syndrome associated with Zika virus infection were reported during the period (14), similar to reports from Brazil and French Polynesia $(26,27)$. There was some difficulty in obtaining data on the expected and observed cases of congenital anomalies in CMS. While some CMS followed the cohort of pregnant women who reported Zika-like symptoms during pregnancy, and evaluated the fetus during pregnancy and after birth, the extent and duration of subsequent postnatal follow-up is unknown and requires further research.

Peak cases were observed in August after the start of the rainy season (usually July-December). This temporal trend was similarly observed in Yap Island, French Polynesia, and Rio de Janeiro, Brazil (9, 14, 28). During the 2013-2014 chikungunya epidemic in some CMS, chikungunya cases demonstrated a similar trend, with peak cases during August-September 2014. ${ }^{\text {a }}$ Recent work conducted by Mordecai et al. suggests that Zika virus transmission by $A e$. aegypti and Ae. albopictus can occur between $18^{\circ} \mathrm{C}$ and $34^{\circ} \mathrm{C}$, with transmission peak at $26^{\circ} \mathrm{C}-29^{\circ} \mathrm{C}$ (29). The tropical-to-subtropical conditions experienced in the Caribbean suggest temperature and climate may contribute

Caribbean Public Health Agency. Chikungunya in CARPHA member states, 2013-2014. Unpublished internal report; 2016. to arboviral transmission. Increased rainfall contributes to increased breeding sites and thus increased mosquito populations.

Surveillance for Zika was implemented relatively quickly in CMS, following previous experience from the 2013-2014 chikungunya epidemic. Suriname was the first CMS to report autochthonous Zika transmission, in October 2015; after this, surveillance was enhanced in all CMS. No significant rise in reported cases of UDF was noted in Suriname's national surveillance data during September 2015. Retrospective investigation showed that Suriname's first four autochthonous Zika cases experienced onset of symptoms the week beginning 4 October 2015 (EW 40). These four cases did not have a history of recent travel from Suriname, were not related to each other, and did not reside in the same place. After confirmation of the initial cases, a significant increase in UDF was observed in Suriname's national surveillance in both the under- and over-5-year age groups. A similar trend was observed in a few other countries and was likely due to enhanced surveillance activities, public health messages about the disease, and presentation of persons with more severe symptoms for health care services.

As testing to detect the virus in mosquitoes was not performed, it is difficult to determine with certainty the mosquito species that contributed to virus transmission. The ubiquitous nature of $A e$. aegypti and documented evidence that this species is a vector of dengue, chikungunya, and other arboviruses in the Caribbean suggests Ae. aegypti could have been a vector of Zika virus during the epidemic (30-32).

Detection of Zika virus RNA in serum of acutely ill patients in the absence of other arboviruses provided evidence that the epidemic was caused by Zika virus. While dengue is endemic, and the chikungunya virus was introduced during the 2013-2014 chikungunya epidemic, none of the patients tested yielded concurrent positive tests for the presence of dengue or chikungunya virus. Low laboratory detection of dengue and chikungunya virus during the review period was likely due to the fact that the Zika epidemic began soon after the chikungunya epidemic, so although chikungunya transmission was likely low, a few cases were still occurring.
Genotypic sequencing determined that the strain circulating in the region was the Asian strain, which is closely related to the strain that circulated in French Polynesia in 2013 (26). Clinical signs and symptoms of Zika virus infection were consistent with those described by both the French Caribbean and Brazil, with rash being the most prominent symptom reported by patients $(5,28)$. There were no reported hospitalizations attributed to the virus during the review period; however, Suriname reported four deaths attributed to the virus (14). It is unknown whether these cases had preexisting comorbidities prior to infection with the virus.

Surveillance for GBS related to Zika infection differed across the CMS, with some countries using the AFP syndrome as a criterion for detection of GBS cases related to Zika infection. During the period, a total of 121 GBS cases were reported from 10 CMS, with 13 GBS cases laboratory-confirmed for Zika virus. There was some difficulty in obtaining data on the expected and observed cases of GBS in CMS. Data reported by Suriname showed a $400 \%$ increase in the incidence of GBS during the weeks of Zika virus transmission compared to pre-Zika baseline incidence (33). This evidence indirectly supports the association between Zika virus and GBS.

A number of strategies were implemented during the Zika epidemic, including public awareness campaigns and vector control measures (application of larvicides and fogging).

\section{Limitations}

This work has some limitations. First, cross-reactivity can occur in flavivirus serological assays. Therefore, prior to serological testing, samples from suspected Zika cases were screened for Zika virus using molecular testing (RT-PCR) (23). The authors believe that molecular testing for the virus in serum collected 1-5 days after onset of illness yielded acceptable results due to the high specificity and sensitivity of the RT-PCR technique used $(100 \%$ and 95\% respectively) (23). Second, while the overall Zika test positivity rate was estimated at $25.8 \%$, individual CMS positivity rates during the epidemic ranged from $<10 \%$ to $38 \%$. Differences in positivity rates across CMS can be 
explained by several factors, including physician difficulty in identifying Zika cases, given the clinical manifestation of the disease common to other arboviral infections; selective sampling of cases for testing, with a bias toward high-risk patients as the epidemic progressed; and possible degradation of the virus in serum samples during storage and transport, if appropriate conditions were not maintained. Finally, attack rates were not calculated and compared across countries because some of the reported rates were suspected to be inaccurate. Potential reasons for unreliable rate estimates include differing sample selection methods utilized within individual CMS and, as $80 \%$ of cases are believed to be asymptomatic (9), the likelihood that mild or asymptomatic cases were missed.

\section{Conclusions}

The emergence and spread of Zika, a reemerging pathogen with the potential to become epidemic, was plausible due to the high volume of intra-regional and international travel, the ubiquitous nature of the Ae. aegypti vector, and a presumed Zika-naïve population. The epidemic highlights the need for continued vigilance and investment in surveillance systems and innovative prevention and control strategies.

Acknowledgments. The authors thank the Ministry of Health staff in CARPHA Member States, for their arduous work during the Zika epidemic; the wider CARPHA staff, for their assistance in the delivery of technical support; and colleagues and partners in the offices of

\section{REFERENCES}

1. World Health Organization. WHO statement on the first meeting of the International Health Regulations (2005) Emergency Committee on Zika virus and observed increase in neurological disorders and neonatal malformations [Internet]. Geneva: WHO; 2016. Available from: http:/ / www.who.int/news-room/ detail/01-02-2016-who-statement-on-thefirst-meeting-of-the-international-healthregulations-(2005)-(ihr-2005)-emergencycommittee-on-zika-virus-and-observedincrease-in-neurological-disorders-andneonatal-malformations Accessed on 21 January 2018.

2. Soper FL. Yellow fever in the Caribbean. Bol Oficina Sanit Panam. 1952;32(3):197205. PMID: 14904527.

3. Brathwaite DO, San Martín JL, Montoya RH, del Diego J, Zambrano B, Dayan GH. The history of dengue outbreaks in the Americas. Am J Trop Med Hyg. 2012;87(4):584-93. doi: 10.4269/ ajtmh.2012.11-0770.

4. Olowokure B, Francis L, Polson-Edwards K, Nasci R, Quénel P, Aldighieri S, et al. The Caribbean response to Chikungunya. Lancet Infect Dis. 2014;14(11):1039-40. doi: 10.1016/S1473-3099(14)70948-X.

5. Daudens-Vaysse E, Ledrans M, Gay N, Ardillon V, Cassadou S, Najioullah $\mathrm{F}$, et al. Zika emergence in the French Territories of America and description of first confirmed cases of Zika virus infection on Martinique, November 2015 to February 2016. Euro Surveill. 2016;21(28):pii=30285. doi: $10.2807 / 1560-$ 7917.ES.2016.21.28.30285.

6. Dirlikov E, Ryff KR, Torres-Aponte J, Thomas DL, Perez-Padilla J, MunozJordan J, et al. Update: ongoing Zika virus transmission-Puerto Rico, November 1, 2015-April 14, 2016. MMWR Morb
Mortal Wkly Rep. 2016;65(17):451-5. doi: 10.15585/mmwr.mm6517e2.

7. Marchette NJ, Garcia R, Rudnick A. Isolation of Zika virus from Aedes aegypti mosquitoes in Malaysia. Am J Trop Med Hyg. 1969;18(3):411-5. PMID: 4976739.

8. Chadee DD, Ward RA, Novak RJ. Natural habitats of Aedes aegypti in the Caribbean-a review. J Am Mosq Control Assoc. 1998;14(1):5-11. PMID: 9599318.

9. Duffy MR, Chen TH, Hancock WT, Powers AM, Kool JL, Lanciotti RS, et al. Zika virus outbreak on Yap Island, Federated States of Micronesia. N Engl J Med. 2009;360(24):2536-43. doi: 10.1056/ NEJMoa0805715.

10. Plourde AR, Bloch EM. A literature review of Zika virus. Emerg Infect Dis. 2016;22(7):1185-92. doi: 10.3201/ eid2207.151990.

11. Rasmussen SA, Jamieson DJ, Honein MA, Peterson LR. Zika virus and birth defects-reviewing the evidence for causality. N Engl J Med. 2016;374(20):1981-7. doi: 10.1056/NEJMsr1604338.

12. Cao-Lormeau VM, Blake A, Mons S, Lastère $S$, Roche $C$, Vanhomwegen $J$, et al. Guillain-Barré syndrome outbreak associated with Zika virus infection in French Polynesia: a case-control study. Lancet. 2016;387(10027):1531-9. doi: 10.1016/ S0140-6736(16)00562-6.

13. Cao-Lormeau V, Roche C, Teissier A, Robin E, Berry AL, Mallet HP, et al. 2014. Zika virus, French Polynesia, South Pacific, 2013. Emerg Infect Dis. 2014;20(6):1084-6. doi: 10.3201/eid2006.140138.

14. Pan American Health Organization. Zika cases and congenital syndrome associated with Zika virus reported by countries and territories in the Americas, 2015-2016: cumulative cases as of 29 December 2016. Washington: PAHO; 2016. Available the Pan American Health Organization (PAHO), the Caribbean Tourism Organization (CTO), the Caribbean Hotel and Tourism Association (CHTA), and other public health organizations. The authors also thank the former director of CARPHA's Surveillance, Disease Prevention and Control Division, Babatunde Olowokure, for technical guidance and support in the development of this manuscript.

\section{Conflicts of interest. None.}

Disclaimer. Authors hold sole responsibility for the views expressed in the manuscript, which may not necessarily reflect the opinion or policy of the RPSP/ $P A J P H$ or the Pan American Health Organization (PAHO). from: http://www.paho.org/hq/index. php?option $=$ com_docman\&task $=$ doc view\&Itemid $=270 \&$ gid $=37582 \&$ lang $=$ en

15. Caribbean Public Health Agency. About the Caribbean Public Health Agency (CARPHA) [Internet]. Port of Spain: CARPHA; 2018. Available from: http:// carpha.org/About Accessed on 10 January 2018.

16. Caribbean Community. Member States and Associate Members [Internet]. Georgetown (Guyana): CARICOM; 2018. Available from: http://caricom.org/ about-caricom/who-we-are/our-governance/members-and-associate-members / Accessed on 10 January 2018.

17. Pan American Health Organization. Health in the Americas+, 2017 edition. Summary: regional outlook and country profiles. Washington: PAHO; 2017. Available from: http://iris.paho.org/ xmlui/handle/123456789/34321

18. Caribbean Community. Agreement establishing the Caribbean Public Health Agency (CARPHA). Georgetown (Guyana): CARICOM; 2011. Available from: http://carpha.org/Portals/0/ docs/CARPHA_IGA.pdf

19. Caribbean Public Health Agency. What we do: laboratory service and networks [Internet]. Port of Spain: CARPHA; 2018. Available from: http://carpha.org/ What-We-Do/Laboratory-Services-andNetworks Accessed on 10 January 2018.

20. Pan American Health Organization. Zika virus infection. Epidemiological Update. 16 Oct 2015. Washington: PAHO; 2015. Available from: https://www.paho.org/ hq/dmdocuments/2016/2015-oct-16-chazika-virus-epi-update.pdf

21. Caribbean Public Health Agency. CARPHA Zika update. 27 Nov 2015. Port of Spain: CARPHA; 2015. 
22. Pan American Health Organization. Zika resources: case definitions [Internet]. Washington: PAHO; 2016. Available from: http://www.paho.org/hq/index. php?option=com_content\&view $=$ article\& id=11117:2015-zika-case-definitions-\& Itemid $=41532 \&$ lang $=$ en Accessed on 31 May 2017.

23. Pan American Health Organization. Algorithm for detecting Zika virus (ZIKV) [Internet]. Washington: PAHO; 2015. Available from: http://www. paho.org/hq/index.php?option $=\mathrm{com}_{-}$ docman\&task=doc_view \& gid = 30176\&Itemid=270 Accessed on 31 May 2017.

24. Caribbean Public Health Agency. Zika virus reaches the Caribbean community [news release]. 12 Nov 2015. Port of Spain: CARPHA; 2015. Available from: http: / / carpha.org/Portals/0/articles / documents/Media\%20Release_Zika\%20 virus.pdf

25. Fine P, Eames K, Heymann DL. "Herd immunity": a rough guide. Clin Infect Dis. 2011;52(7):911-6. doi: 10.1093/cid/cir007.

26. Cauchemez S, Besnard M, Bompard P, Dub T, Guillemette-Artur P, Eyrolle-Guignot
D, et al. Association between Zika virus and microcephaly in French Polynesia, 2013-15: a retrospective study. Lancet. 2016;387(10033):2125-32. doi: 10.1016/ S0140-6736(16)00651-6.

27. de Araújo TVB, Rodrigues LC, de Alencar Ximenes RA, de Barros Miranda-Filho D, Montarroyos UR, de Melo APL, et al. Association between Zika virus infection and microcephaly in Brazil, January to May, 2016: preliminary report of a case-control study. Lancet Infect Dis. 2016;16(12):1356-63. doi: 10.1016/ S1473-3099(16)30318-8.

28. Ioos S, Mallet HP, Leparc Goffart I, Gauthier V, Cardoso T, Herida M. Zika virus epidemiology and recent epidemics. Med Mal Infect. 2014;44(7):302-7. doi: 10.1016/j.medmal.2014.04.008.

29. Mordecai EA, Cohen JM, Evans MV, Gudapati P, Johnson LR, Lippi CA, et al. Detecting the impact of temperature on transmission of Zika, dengue, and chikungunya using mechanistic models. PLoS Negl Trop Dis. 2017;11(4):e0005568. doi: 10.1371/journal.pntd.0005568.

30. Brasil P, Calvet GA, Siqueira AM, Wakimoto M, Carvalho de Sequeira P,
Nobre A, et al. Zika virus outbreak in Rio de Janeiro, Brazil: clinical characterization, epidemiological and virological aspects. PLoS Negl Trop Dis. 2016;10(4):e0004636. doi: 10.1371/journal.pntd.0004636.

31. Marchette NJ, Garcia R, Rudnick A. Isolation of zika virus from Aedes aegypti mosquitoes in Malaysia. Am J Trop Med Hyg. 1969;18(3):411-5. PMID: 4976739.

32. Boorman JP, Porterfield JS. A simple technique for infection of mosquitoes with viruses; transmission of Zika virus. Trans R Soc Trop Med Hyg. 1956;50(3):238-42. PMID: 13337908.

33. Dos Santos T, Rodgriguez A, Almiron M, Sanhueza A, Ramon P, de Oliveira WK et al. Zika virus and the Guillain-Barré Syndrome-case series from seven countries. N Engl J Med. 2016;375(16):1598-601. doi: 10.1056/NEJMc1609015.

Manuscript submitted 26 February 2018. Revised version accepted for publication on 1 June 2018.
RESUMEN

\section{Brote epidémico del virus del Zika en 19 países y territorios del Caribe de habla inglesa y holandesa en el período 2015-2016}

\author{
Palabras clave
}

Tras la aparición del virus del Zika en Brasil en mayo del 2015, los países de habla inglesa y holandesa reforzaron la vigilancia de este virus. El primer caso autóctono de infección por el virus del Zika en el Caribe fue notificado por Suriname en noviembre del 2015 y desde entonces el virus se ha propagado rápidamente en toda el área. Los Estados Miembros del Organismo de Salud Pública del Caribe (CARPHA, por su sigla en inglés) notificaron casos presuntos de infección por el virus detectados clínicamente y entregaron al Organismo muestras de suero para que se llevaran a cabo las pruebas de laboratorio. Se consideró que un paciente era un caso confirmado si se detectaba el virus del Zika mediante la prueba serológica de la reacción en cadena de la polimerasa con retrotranscriptasa en tiempo real. Habida cuenta de la relación documentada entre 1) el virus del Zika y el síndrome congénito y 2) el virus del Zika y el síndrome de Guillain Barré, se buscaron datos sobre los resultados relativos a ambas enfermedades en los informes nacionales y regionales. En este informe especial se describen las características epidemiológicas de los casos de infección por el virus del Zika notificados al CARPHA, confirmados mediante pruebas de laboratorio, incluidos los vínculos con el síndrome congénito y el síndrome de Guillain Barré, en 19 países del Caribe de habla inglesa y holandesa en el período de la epidemia (del 1 de octubre del 2015 al 29 de diciembre del 2016).

Enfermedades transmisibles emergentes; epidemias; virus Zika; región del Caribe. 
RESUMO

Surto causado pelo vírus zika em 19 países e territórios do Caribe de língua inglesa e holandesa, 2015-2016

A vigilância do zika foi melhorada nos países e territórios do Caribe de língua inglesa e holandesa com a emergência da doença no Brasil em maio de 2015. O primeiro caso autóctone de zika no Caribe foi registrado no Suriname em novembro de 2015 e, desde então, o vírus tem se propagado rapidamente em toda a região. Os Estados Membros da Agência de Saúde Pública do Caribe (CARPHA) notificaram casos com suspeita clínica de zika e enviaram amostras séricas para análise laboratorial. Considerou-se caso confirmado quando houve a detecção do vírus zika com a técnica de reação em cadeia da polimerase da transcrição reversa em tempo real (PCR-RT) ou com teste sorológico. Devido à associação comprovada entre o vírus zika e a síndrome congênita e o vírus zika e a síndrome de Guillain-Barré (SGB), foram obtidos dados relativos a estes desfechos dos registros regionais e dos países. Este informe especial faz uma descrição da epidemiologia dos casos de zika com confirmação laboratorial notificados à CARPHA, incluindo casos associados à síndrome congênita e SGB, nos 19 países do Caribe de língua inglesa e holandesa no período epidêmico (de 1o de outubro de 2015 a 29 de dezembro de 2016).

Palavras-chave Doenças transmissíveis emergentes; epidemias; Zika virus; região do Caribe 